\title{
THE IMPACT OF CEMETERIES IN KRAKOW ON THE NATURAL ENVIRONMENT - SELECTED ASPECTS
}

\author{
JÓZEF ŻYCHOWSKI \\ Pedagogical University of Cracow, Institute of Geography, \\ Podchorążych 2, 30-084 Kraków, Poland, \\ E-mail: jozyk@wp.pl
}

\begin{abstract}
In order to show the influence of selected cemeteries in Krakow on components of environments, the element contents in the ground over burials, in the clover and fungi as well as the ions concentration in the ground waters, were investigated. The results were compared to the geological background and to the measurements taken on other cemeteries in south-east Poland. The attention was also drawn to geological products of decomposition. Over burials low contents of elements were confirmed. High iron ion concentration in ground water indicates its useful presence in deposits for decomposition products sorption. Relatively low pollutants concentrations are related to advantageous locations of the cemeteries; deep level of ground water, the presence of absorbents in the deposits, surfaces of cemeteries are impervious and passable dehydration systems.
\end{abstract}

Key words: localization of cemeteries, Cracow, migration of the matter, ground water, ions, the element contents

\section{INTRODUCTION}

Studies carried out to-date have indicated that cemeteries could adversely affect the environment because of their incorrect placement and lack of precautions against migration of pollutants (Fisher and Croukamp 1993). This issue has not yet been properly regulated by law. The first European study pertaining to the impact of cemeteries on the environment was conducted by van Haaren (1951). This issue was also investigated by the World Health Organisation (Ucisik and Rushbrook 1998). The references in this last document describe both shortand long-term adverse impacts of necropoles on the environment. The studies completed to-date in the vicinity of graves, have found increased concentrations of the following: intestinal bacteria (Dent and Knight 1998;
Matos 2001), ions and elements (Pacheco et al. 1991; Knight and Dent 1995; Spongberg and Becks 2000; Trick et âl. 2001; Harmse and Tumagole 2006; Zychowski et al. 2006b; Żychowski 2008), aminoacids (Zychowski et al. 2001, 2003), organic acids in ground waters (Zychowski 2007), and cadaveric poison (Forbes et al. 2002).

\section{OBJECTIVE AND METHODS OF STUDIES}

The subject of this investigation is the impact of Krakow's cemeteries on selected components of the natural environment. Attention was brought to the consequences of burying large numbers of human corpses on relatively small areas. As proven in a number of studies, conducted in the world as well as in Poland, the products of decomposition occur 
chiefly in the substrate and water, where they migrate together with water, as ions, to the surroundings of graves (Pacheco et al. 1991; Dent and Knight 1998; Matos 2001; Spongberg and Becks 2000; Żychowski 2008). In this study, the content of elements was analysed in the substrate above the burial sites, in clover, fungi growing on graves, as well as in the contents of selected aminoacids in ground water below and in the vicinity of graves.

In this study, the results obtained from Krakow's cemeteries were compared with those obtained in other cemeteries in south-eastern Poland (Zychowski et al. 2002, 2003, 2005; Zychowski 2008). The comparisons of element content in the substrates and of ions in water were also made with the data from studies undertaken abroad (Dent and Knight 1998; Knight and Dent 1998; Trick et al. 2001). Particular attention was paid to the natural environment of necropoles. The results obtained to-date, indicate the considerable effect of the location of cemeteries on the concentrations of certain elements.

The concentrations of $\mathrm{Ca}, \mathrm{P}, \mathrm{Fe}$ and $\mathrm{Cr}$ were measured in the collected samples of the substrate, of which $\mathrm{Ca}$ and $\mathrm{P}$ predominate in human bodies (Dent and Knight 1998; Ucisik and Rushbrook 1998). Iron $(\mathrm{Fe})$ is a basic indicator of the properties of the soil environment and is an efficient absorbent e.g. of phosphorus ions. The ions or hydrated iron oxides form soluble or insoluble compounds with decomposition products. Chromium (Cr), a trace element of the iron group (technological groups) is essential to the human organism and occurs in the substrate and plants, as well as in items associated with burials.

The samples of substrates from cemeteries were collected from the depth of ca. 0.2 $\mathrm{m}$ below the humus layer (A). This level is only very rarely present at cemetery sites because of permanent digging and earth work. The studies allowed for an assessment of the impact exerted by burials on the substrate in the upper sections of horizontal profiles. The samples of substrate from greater depths were collected only in Grębalow, in the eastern, lower part of the cemetery. It was only in this location where permission was obtained to collect the earth from digging new graves in the place of earlier burials. Therefore the analysis pertained chiefly to the mineralogical-petrographical products which are formed at burial sites. The material was obtained from the following depths: $0.31-0.35 \mathrm{~m}, 0.65-0.69 \mathrm{~m}, 1.05-1.09$ $\mathrm{m}, 1.36-1.40 \mathrm{~m}$, and $1.55-1.59 \mathrm{~m}$.

In the case of cemeteries situated on slopes, the samples of ground and plants were collected from the lower portion of the slope. In the case of flat surfaces - and these were predominant - the material for analyses was collected from the central parts of the facilities. In each of the cemeteries, around these places there were earth burials. These were primarily responsible for the impact of burials on the environment. The only plant occurring in the majority of the studied cemeteries was red clover (Trifolium pratense $L$.) and the $\mathrm{P}$ and $\mathrm{Ca}$ concentrations taken from its leaves were determined. Additional measurements of the concentrations of these elements were conducted in the neighbourhood of the studied cemeteries, in order to obtain the biogeochemical background. These places were selected in the way that excluded the effects of graves upon the sampling sites.

In the dried caps of mushrooms, the concentrations of $\mathrm{P}, \mathrm{Fe}$ and $\mathrm{Pb}$ were determined. The mushrooms were of various species and thus the comparisons between concentrations bore a unspecified error. The mushrooms possess the ability to synthetise polyphenylic pigments which bind heavy metals such as $\mathrm{Pb}, \mathrm{Zn}, \mathrm{Cd}$, and $\mathrm{Cs}$. The mycelium immobilises heavy metals and curbs their transfer to plant tissues (Khan et al. 2000). The mycorrhysis thus enhances the tolerance of plants to toxic concentrations of heavy metals in soils (Krupa and Kozdroj 2004). The excess of heavy metals in the substrate is bound in the electronegative places in the cell walls in mycelia, or these elements are immobilised by being precipitated in the form of polyphosphates (Tam 1995). The mycelia of some strains of fungi tolerate increased concentrations of heavy metals and 
some are capable of bearing concentrations of heavy metals some several times higher, in comparison to plants (Joner et al. 2000). The evaluation of the substrate toxicity may thus be carried out by measuring the level of mycorrhiza (the degree of colonisation, abundance of arbuscule formation, or vitality of mycorrhizas and spores) and not using only chemical methods (Lovera and Cuenca 1996). The mycelium develops a network of hyphae and releases substances binding or gluing soil particles (Miller and Jastrow 2000). Our knowledge about mycorrhizal fungi is, however, far from complete (Smith and Read 1997).

The ground water was collected from wells, walled and currently in use and mostly covered by certain boards. The samples were frozen in a thermos-flask and transported to the laboratory. Water collected from the cemeteries at Rakowicka Street, and Prandoty Street was examined for concentrations of 11 ions: nitrates, ammonium, sulphate, phosphate, fluoride, chloride, iron, manganese, zinc, copper, and aluminium. Only the phosphate, nitrate, copper and iron ions were selected for comparisons. These represent the decomposition products as well as the environment of the burial sites and they participate in the processes producing new compounds (Zychowski et al. 2006a; Zychowski 2008). In the presented study, the results were also compared with the allowable levels set in the Ordinance by the Minister of Environmental Protection of 11 February 2004 (Dziennik Ustaw [The Official Journal of Laws] No. 32, item 284).

The contents of selected aminoacids (lysine, glycine, leucine, isoleucine, and glutamic acid ${ }^{1}$ ) in the ground waters of Krakow's

\footnotetext{
${ }^{1}$ As a result of decarboxylation processes and with the participation of bacteria, lysine can decompose in putrefaction processes to produce cadaverine, which is colloquially termed 'cadaveric poison'. At higher concentrations it is toxic to humans. Glycine is the simplest of àll àminoacids, and a component of any protein, pariticularly collagen. Glutamic acid, glycine, leucine, and isoleucine dissolve well in water. These compounds may be easily transported over great distances. Leucine and isoleucine demonstrate strong hydrophobic properties and form a very stable structure in aquatic environments.
}

cemeteries was also compared with those in the samples collected in other cemeteries of south-eastern Poland (Zychowski et al. $2002,2003,2005)$. As the relevant data are lacking, no comparisons could be made with sites elsewhere in the world.

The samples were first air dried in the open, then laser dried, and later subjected to a procedure following the requirements of atomic absorption spectrophotometry for (ASA) manufactured by Perkins Elmer (AAnalist 200). In the spectrometer, the relative content of 20 elements in the substrate was measured (elimination of background) as well as their absolute concentration levels in clover and fungi. The analysis of water was conducted with the use of a Varian HPLC liquid chromatograph. The mineralogical-petrographical studies were carried out using a universal polarizing microscope Olympus BX-51 and a scanning microscope Joel 540, with an EDS attachment for semi-quantitative chemical analyses. Use of the EDS attachment (Energy Dispersive Spectrometry) enables the determination of changes in contents of selected elements along the scanning line.

\section{STUDY AREA}

The studies of substrate were conducted in the following Kraków cemeteries: Podgorski (1900), Rakowicki (1801/2), the military cemetery at Prandoty Street (graves of the Soviet and British soldiers), Grębałowski (1964), and the Jewish cemetery, and also in the area of the former WWII concentration camp in Płaszów where the ashes of several thousand people were scattered in 1944 (Tables 1,2,3). The sites were chosen so as to represent the diversity among the locations of cemeteries in Kraków (Fig. 1).

In the case of $\mathrm{P}, \mathrm{Ca}$ and $\mathrm{Cr}$, their concentrations in the substrate above the burial plots in Krakow's cemeteries were compared with those measured in the substrate from cemeteries situated in Dukla, Nowy Sącz, and Tarnów (Tables 1,2,3). The mass graves, compared in this study, are earth 
Table 1. A characterization of the geographical environments at the cemeteries where concentrations of elements in soils were investigated

\begin{tabular}{|c|c|c|c|c|c|c|}
\hline Cometeries & No. of buried & $\begin{array}{l}\text { (iendraphical } \\
\text { region }\end{array}$ & Relicf & $\begin{array}{l}\text { Surroundings } \\
\text { of grave }\end{array}$ & Inclination & $\begin{array}{l}\text { Substratum } \\
\text { humidity }\end{array}$ \\
\hline $\begin{array}{l}\text { Kraków, Plaszów, } \\
\text { mass, WWII, cemp }\end{array}$ & about 9000 & $\begin{array}{l}\text { Isolated horsts } \\
\text { of the Crescovian } \\
\text { Citle }\end{array}$ & $\begin{array}{l}\text { slops: of the } \\
\text { culcureous } \\
\text { horst }\end{array}$ & $\begin{array}{l}\text { ont spilt } \\
\text { remesins }\end{array}$ & to $5 \%$ & $\begin{array}{l}\text { sands, clays, marls: } \\
\text { lowlly wet }\end{array}$ \\
\hline $\begin{array}{l}\text { Krakowi, } \\
\text { Podgórski, clin., } \\
\text { WWI }\end{array}$ & $\begin{array}{l}>3.32 \text { ', since } \\
\text { the year } 1900\end{array}$ & & $\begin{array}{l}\text { Met area in } \\
\text { the middle } \\
\text { part of the } \\
\text { slops? }\end{array}$ & other tgreves & $10.3 \%$ & $\begin{array}{l}\text { sands, clays, mark; } \\
\text { dry }\end{array}$ \\
\hline $\begin{array}{l}\text { Krakóm, } \\
\text { irẹtaltinz, cm. }\end{array}$ & $\begin{array}{l}>100^{2}, \sin x \\
\text { the year } 1964\end{array}$ & Kraków Upland & $\begin{array}{l}\text { Flat arca at } \\
\text { the foot of the } \\
\text { slope }\end{array}$ & other grawes & to $3 \%$ & $\begin{array}{l}\text { locsses; } \\
\text { dry }\end{array}$ \\
\hline $\begin{array}{l}\text { Clarnow, Stary" } \\
\text { Cemetery }\end{array}$ & $\begin{array}{l}>100^{\circ}, X I X . \\
X X a g ?\end{array}$ & 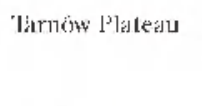 & $\begin{array}{l}\text { terrefce of } \\
\text { Wątok Riwer }\end{array}$ & mainly tombs & П拉 & $\begin{array}{l}\text { clays, perasels; } \\
\text { periodically } \\
\text { flooded }\end{array}$ \\
\hline $\begin{array}{l}\text { Nowy Sacz, cm., } \\
\text { mass, } \\
\text { wwi }\end{array}$ & $>200^{\prime}$ & Sạcz Basin & $\begin{array}{l}\text { high } \\
\text { river-terrace }\end{array}$ & other grawes & flat & $\begin{array}{l}\text { clays, loams, } \\
\text { grapels; } \\
\text { dry }\end{array}$ \\
\hline $\begin{array}{l}\text { Dukla, } \\
\text { mass, WWI }\end{array}$ & $>750^{\circ}$ & Jaslo Foothills & $\begin{array}{l}\text { foot of the } \\
\text { slope }\end{array}$ & $\begin{array}{l}\text { grawes of } \\
\text { Wwil soldiers }\end{array}$ & to $3 \%$ & $\begin{array}{l}\text { clays, loams: } \\
\text { periodiceslly wet }\end{array}$ \\
\hline
\end{tabular}

${ }^{1}$ WWI burial site of reduced area, Nowy Cmentarz Podgórski - 8.33 ha;

${ }^{2}$ samples taken from large cemeteries, Grębalów - 28000 graves, Tarnów „Stary” - 80,000 dead:

${ }^{3}$ estimated number; the older part of the municipal cemetery has 10,000 graves;

${ }^{4}$ estimated number in the proximity of WWII cemeteries, where about 10,000 soldiers were buried; mass graves from WWI, WWII; cm. - cemetery.

Source: Data from author's measurements, as well as the other tables and Figs. 2-10.

graves without any horizontal concrete surfácès.

The contents of $\mathrm{P}, \mathrm{Pb}$ and $\mathrm{Fe}$ were also compared in fungi collected in the Rakowicki cemetery, from mass graves in Bór, Oświęcim, and Barwinek as well as on the Malastowska Pass and the cemetery in Krosno (Table 2).

The contents of $\mathrm{Ca}$ and $\mathrm{P}$ in red clover found in the cemetery in Zbylitowska Góra and on the mass graves in Dukla and Zbylitowska Góra, were then compared with the corresponding data obtained for samples from the following cemeteries in Kraków: Rakowicki, military cemetery at Prandoty Street and the Jewish cemetery in Płaszów (Table 3).

The concentrations of nitrate, iron, and copper ions in water from the cemeteries in Wojnicz, Rymanów, Biecz, Oświęcim, and Zakliczyn were compared with corresponding concentrations in Wolverhampton (Żychowski 2008; Trick et al. 2001). The contents of phosphate ions in Rymanów, Zakliczyn, Wojnicz, and Biecz were compared with data from Adelaide and Perth in Australia, available in the relevant publications (Żychowski 2008; Dent and Knight 1998; Dent 2000a and b). In the cemeteries under study, the wells sampled were those situated amidst graves, near the central parts of the necropoles. This principle was also upheld in the cemeteries at Rakowicka Street and Prandoty Street. Only the covered well in Biecz is situated ca. $15 \mathrm{~m}$ below the WWI mass grave which was sited in the upper part of a sliding slope, and the household well in Oświęcim is situated at a distance of ca. 
Table 2. A characterization of the geographical environment at the cemeteries where concentrations of elements in fungi and soils were investigated

\begin{tabular}{|c|c|c|c|c|c|c|}
\hline Cemeteries & No. of buried & $\begin{array}{l}\text { (jeographical } \\
\text { region }\end{array}$ & Relief & $\begin{array}{l}\text { Surroundings } \\
\text { of fyrewe }\end{array}$ & $\begin{array}{l}\text { Ciround water } \\
\text { level' }(m)\end{array}$ & Substratum \\
\hline $\begin{array}{l}\text { Kraków, } \\
\text { Rakinicé, messi }\end{array}$ & $>1100^{2}$ & $\begin{array}{l}\text { Nacturišlan̂ska } \\
\text { I'lain }\end{array}$ & $\begin{array}{l}\text { flat, alluwial } \\
\text { cone I'rądinik }\end{array}$ & $\begin{array}{l}\text { grawes em. } \\
\text { a city centre }\end{array}$ & $6-8$ & $\begin{array}{l}\text { grawels, sands, } \\
\text { silts, peat, }\end{array}$ \\
\hline Bór , mass, WWII & about $\$ 000$ & $\begin{array}{l}\text { Kollyszowa } \\
\text { Plateau }\end{array}$ & $\begin{array}{l}\text { flat, next door } \\
\text { to dune }\end{array}$ & $\begin{array}{l}\text { a glade in the } \\
\text { reservation } \\
\text { "I3or" }\end{array}$ & $1-2$ & $\begin{array}{l}\text { sauds, sands } \\
\text { loamy }\end{array}$ \\
\hline $\begin{array}{l}\text { Oszrięcim remains, } \\
\text { mass, WWII }\end{array}$ & $\begin{array}{l}>\text { hundreds of } \\
\text { thousands }\end{array}$ & Oświẹcim I3asin & $\begin{array}{l}\text { a lerrace cul } \\
\text { with ditehes }\end{array}$ & pine tyrove & $2-4$ & $\begin{array}{l}\text { clays, loems, } \\
\text { grawels. }\end{array}$ \\
\hline $\begin{array}{l}\text { I3anwinek, mass, } \\
\text { WWII }\end{array}$ & atoout 5000 & Iow I3eskid & $\begin{array}{l}\text { flattening in } \\
\text { the foot of the } \\
\text { slope }\end{array}$ & forest-glade & $>10$ & cleys, keams \\
\hline $\begin{array}{l}\text { Przelecz } \\
\text { Malastowiska, } \\
\text { mass, WWI }\end{array}$ & about 174 & Low Beskid & $\begin{array}{l}\text { mountain } \\
\text { mest }\end{array}$ & forest-glade: & $>10$ & $\begin{array}{l}\text { clays, rubble, } \\
\text { sandstones }\end{array}$ \\
\hline $\begin{array}{l}\text { Krosno, cm., mass, } \\
\text { WwI }\end{array}$ & $>200$ & Krosno Basin & $\begin{array}{l}\text { terrace of } \\
\text { I_ubatowika }\end{array}$ & $\begin{array}{l}\text { grawes of em., } \\
\text { roed }\end{array}$ & $6-8$ & $\begin{array}{l}\text { clays, dusts, } \\
\text { travels. }\end{array}$ \\
\hline
\end{tabular}

* at this cemetery soil was also investigated;

${ }^{1}$ established by reference to observations of ground water levels in the field;

${ }^{2}$ victims of the camp at Dąbie (1918-1921), a similar environment at the cemetery from WWI:

${ }^{3}$ possible influence of other neighbouring graves, Rakowice $-75,000$ graves;

${ }^{4}$ reduced-burial area, 22,000 people buried at the cemetery.

$150 \mathrm{~m}$ from a large cemetery housing the remains of some 6000 Soviet POWs).

The studies on the concentrations of selected aminoacids were carried out in the cemeteries at Prandoty Street and Rakowicka Street (Táble 4). The results were compared with the concentrations of these aminoacids in water from other wells; namely: near the cemetery of POWs in OswięcimBrzezinka, in the cemetery in Rymanow, and the well below the WWI mass grave in Biecz, as well as with the average values calculated for 71 cemeteries studied in south-eastern Poland (Zychowski et al. 2001, 2002, 2005).

\section{CONTENT OF SELECTED ELEMENTS IN THE SUBSTRATE}

The $\mathrm{P}$ content is a proven indicator of the impact of cemeteries on the environment (Arrhenius 1929; Marcinek and Wislanski 1959). The proportion of this element in the chemical composition of the human body is ca. $1 \%$. In the ground above the burial plots in the cemeteries at Rakowicka and Prandoty Street, the relatively low concentrations of this element were found - from $7.2 \mathrm{ppm}$ to $12.3 \mathrm{ppm}$ (Fig. 2). Markedly higher concentrations of $P$ were found in the Podgorze cemetery and within the area of the former concentration camp in Płaszów, where respectively, 36.6 and $29.4 \mathrm{ppm}$ P were found (Fig. 2). Slightly higher concentration of $\mathrm{P}$ above the burial plots in Płaszów and Podgórze is coupled with the relatively higher content of $\mathrm{Ca}-39.4$ and $37.2 \mathrm{ppm}$ respectively, in comparison to the concentration above the WWI grave in the cemetery at Rakowice Street (1.9 ppm), and on the WWII grave of British soldiers at Pranndoty Street - 3.7 ppm (Fig. 2). Concentrations of $\mathrm{P}$ in the Podgórze and Płaszów sites are, however, definitely lower than those found in other cemeteries, e.g. situated on the riverine terraces of the Stary Cmentarz 
Table 3. A characterization of the geographical environments at the cemeteries where concentrations of elements in clover and soils were investigated

\begin{tabular}{|c|c|c|c|c|c|}
\hline Cemeleries & No. of huried & $\begin{array}{l}\text { Gicographical } \\
\text { region }\end{array}$ & Relier & Inclination & Subsiratum \\
\hline $\begin{array}{l}\text { Kraków, Rakowice, mass, } \\
1919-1921\end{array}$ & $>1100^{1}$ & $\begin{array}{l}\text { Nadwiślańska } \\
\text { Plain }\end{array}$ & $\begin{array}{l}\text { alluvial cons: } \\
\text { Prądnik }\end{array}$ & flat & $\begin{array}{l}\text { graw:ls, sands. } \\
\text { silts, peat. }\end{array}$ \\
\hline Kraków, Prandoty, mass, Sov? & $>2000$ & & & to $3 \%$ & \\
\hline Kraków, Plaszów, m. Jcw. & $\begin{array}{l}\text { fragment, about } \\
500\end{array}$ & $\begin{array}{l}\text { isolated horsts } \\
\text { of the Cracotian } \\
\text { Cirle }\end{array}$ & $\begin{array}{l}\text { horst of } \\
\text { Bonarka }\end{array}$ & to $7 \%$ & $\begin{array}{l}\text { clays, loams, } \\
\text { marls }\end{array}$ \\
\hline Zlwhlitowska Gióra, mass WWII & about 10000 & $\begin{array}{l}\text { yalley of Dunajes } \\
\text { River near } \\
\text { Tarnow }\end{array}$ & $\begin{array}{l}\text { escarpment of } \\
\text { the terrace of } \\
\text { Dumajec River }\end{array}$ & to $8 \%$ & Enavels, clays \\
\hline Fhylitowska (fóra com. & $\begin{array}{l}\text { about } 2000, \mathrm{XX} \\
\text { ane }\end{array}$ & & $\begin{array}{l}\text { terrace of } \\
\text { Dumajec }\end{array}$ & Mèt & cleyss \\
\hline Dukle, mas, WwII & $>10(1000$ & Jasto loothills & $\begin{array}{l}\text { slope of the } \\
\text { small valley }\end{array}$ & $102 \%$ & cleys, Kems \\
\hline
\end{tabular}

${ }^{1}$ possible impact of other adjacent graves;

${ }^{2}$ Soviet soldiers, similar conditions relate to graves of British soldiers;

${ }^{3}$ surviving part of the Jewish Cemetery (Jew.) generally destroyed by the Nazis.

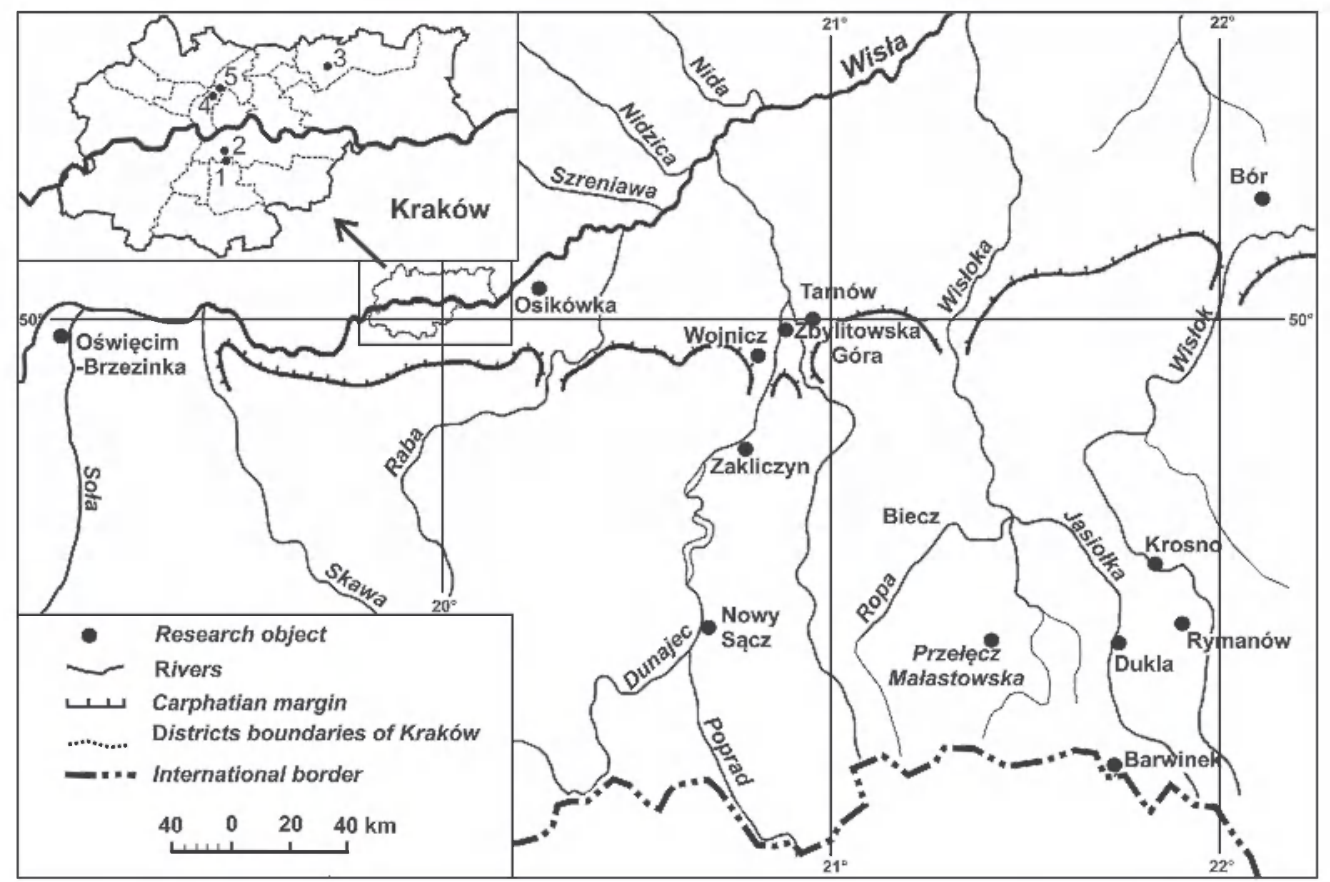

Figure 1. Locations of research sites (locations of cemeteries in Cracow:

1 - Płaszow, 2 - Podgorze, 3 - Grębalow, 4 - Rakowice, 5 - Pradoty St.) 
Table 4. A characterization of the geographical environments at the cemeteries where concentrations of ions in ground water were investigated

\begin{tabular}{|c|c|c|c|c|c|}
\hline Cemeteries & Relief & Inclination & $\begin{array}{l}\text { Gound water } \\
\text { level' }(\mathbf{m})\end{array}$ & Water outflow & Subsiratum \\
\hline Kraków, Rakowice, cm. & \multirow{2}{*}{$\begin{array}{l}\text { alluyial cone of } \\
\text { l’ạdnik stream }\end{array}$} & \multirow[t]{2}{*}{ flat, to $2 \%$} & $7,5-8$ & \multirow{2}{*}{$\begin{array}{l}\text { sewage system, } \\
\text { infiltration. }\end{array}$} & \multirow{2}{*}{$\begin{array}{l}\text { sands, gravels, silts, } \\
\text { peat, rubthle. }\end{array}$} \\
\hline $\begin{array}{l}\text { Kraków, Prandoty, cm., } \\
\text { WWII }\end{array}$ & & & $6,5-7$ & & \\
\hline Biccz, mass, WWI & $\begin{array}{l}\text { slope of the valley } \\
\text { of Ropa River }\end{array}$ & $\begin{array}{l}\text { slope, terrace, } \\
\text { to } 20 \%\end{array}$ & $1-1,2$ & $\begin{array}{l}\text { percolation of } \\
\text { weler in the } \\
\text { landslide }\end{array}$ & clays of colluvium \\
\hline $\begin{array}{l}\text { Ckizieccim, I3rzezinkes, } \\
\text { mass, WWII }\end{array}$ & $\begin{array}{l}\text { terrace of Sola, } \\
\text { Wisla River }\end{array}$ & Mát & $.3,3-3,3,5$ & ditches drainatge & $\begin{array}{l}\text { clays, oams, geravels; } \\
\text { winds }\end{array}$ \\
\hline Ryı17าancow, c17. & $\begin{array}{l}\text { slope of laymanowi } \\
\text { IIilks }\end{array}$ & $\begin{array}{l}\text { differentiated, } \\
\text { to } 7 \%\end{array}$ & $4-4.5$ & $\begin{array}{l}\text { overland (sireet) } \\
\text { Monz }\end{array}$ & $\begin{array}{l}\text { clays, loams. } \\
\text { wmdstomes }\end{array}$ \\
\hline Wojnicf., $\mathrm{cm}$. & terrace of Dumajec & ח主 & $3,5-4$ & $\begin{array}{l}\text { infiltration. } \\
\text { ditches drainatge }\end{array}$ & $\begin{array}{l}\text { winds, silts, clays. } \\
\text { peat }\end{array}$ \\
\hline Zisklickyn, cור. & $\begin{array}{l}\text { hijh terrace in the } \\
\text { valley of Dunajec } \\
\text { Riwer }\end{array}$ & $\begin{array}{l}\text { differentiated, } \\
\text { to } 3 \%\end{array}$ & $4,5-.5,5$ & $\begin{array}{l}\text { infiltration, } \\
\text { overland (shect) } \\
\text { flow }\end{array}$ & $\begin{array}{l}\text { clays, rubble, below } \\
\text { grawels, sands }\end{array}$ \\
\hline Adelaide', cm. & $\begin{array}{l}\text { terrace of Torrens, } \\
\text { Adelaide Plain }\end{array}$ & flat & $4-4.7$ & $\begin{array}{l}\text { infiltration. } \\
\text { overland (shect) } \\
\text { flow }\end{array}$ & $\begin{array}{l}\text { sandy days, sandy } \\
\text { loams }\end{array}$ \\
\hline Perth $^{2}, \mathrm{~cm}$ & $\begin{array}{l}\text { scaside-plain, } \\
\text { sea-sediments }\end{array}$ & $\begin{array}{l}\text { differentiated, } \\
\text { to } 3 \% \text {. }\end{array}$ & $1,8-4,5$ & $\begin{array}{l}\text { infiltration, } \\
\text { overland (shect) } \\
\text { tlow }\end{array}$ & $\begin{array}{l}\text { clean, clayey or } \\
\text { muddy sands }\end{array}$ \\
\hline Wolverhampton $\mathrm{em}$. & $\begin{array}{l}\text { wawy postglacial } \\
\text { relief }\end{array}$ & $\begin{array}{l}\text { differentiated, } \\
\text { to } 5 \%\end{array}$ & $2-10$ & $\begin{array}{l}\text { infiltration. } \\
\text { overland (sweet) } \\
\text { llow }\end{array}$ & sands, clays \\
\hline
\end{tabular}

\footnotetext{
${ }^{1}$ Cheltenham Cemetery (Knight, Dent, 1998);

${ }^{2}$ Guildford Cemetery (Dent, Knight, 1998; Dent 2000);

${ }^{3}$ Wolverhampton (Trick et al., 2001).
}

(old cemetery) in Tarnów (87.4 ppm), in Oświęcim (1000 ppm), and on the slope in Dukla - 2984 ppm (Źychowski 2008).

A relatively higher $\mathrm{Ca}$ content found in some of the Krakow cemeteries is associated also with the geological structure. It is particularly evident on the slope of the limestone horst in Płaszów, and - to a lesser degree - on a local plateau site in Podgórze (Table 1). Also smaller is perhaps the effect of the alluvial fan of the Prądnik stream on the Ca concentration in the cemeteries at Rakowicka Street and Prandoty Street. At times, rubble containing pieces of limestone, was sometimes added to some sections of these cemeteries or used as a base course when cemetery alleys were built as in the sections containing the graves of WWI soldiers. Limestone rubble was also used to form the ground embankments of a few graves. At this stage of the research it has not been possible to determine the source of origin of the $\mathrm{Ca}$.

The $\mathrm{Ca}$ content near the graves in the Rakowicka and Prandoty cemeteries is, however, definitely lower than those measured at other cemeteries, similarly situated on riverine terraces, e.g. in Tarnów (19.4 ppm) and Nowy Sącz (35.4 ppm). These results indicate the greater effect of both these cemeteries upon the $\mathrm{Ca}$ concentration, be- 


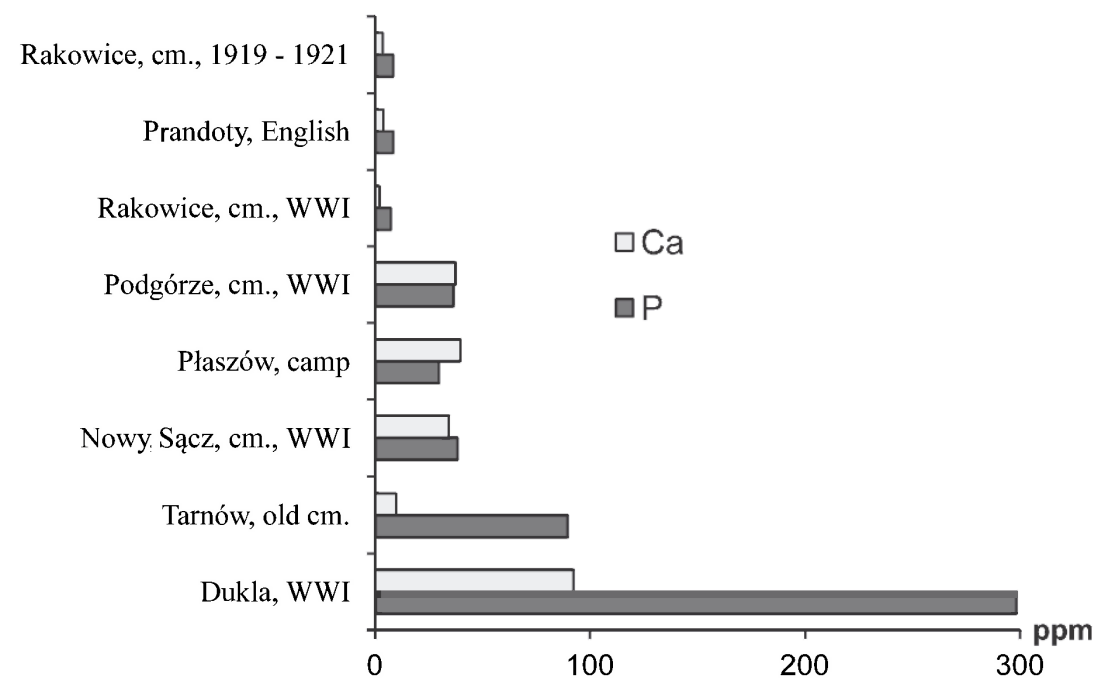

Figure 2. P and Ca contents in samples of substratum collected from the above graves at selected cemeteries. Explanations as in the tables

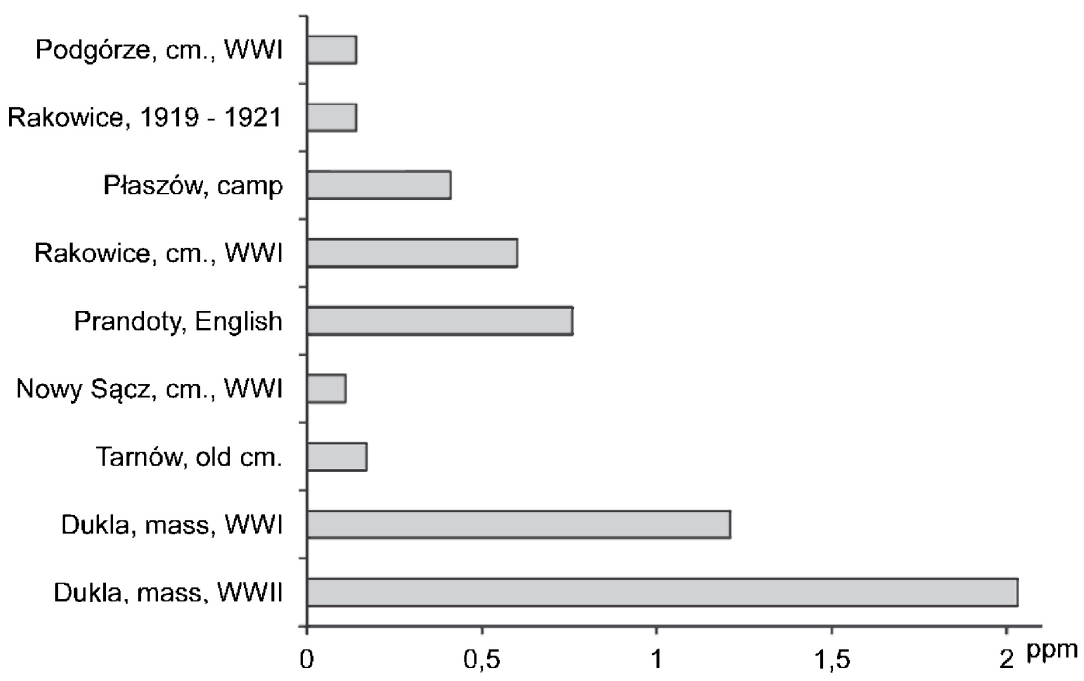

Figure 3. Cr contents in soil samples collected at near-surface level in selected cemeteries.

Explanations as in the tables

cause limestone rubble does not appear in the riverine sediments in either the Wątok river (Tarnów) nor Kamienica Nawojowska (Nowy Sącz).

Iron is an important element which is an absorbent of P (Żychowski et al. 2006b; Żychowski 2008). A relatively higher Fe con- centration above the burial plots occurs on a unlevelled slope in Płaszów (ca. 26 ppm) and in the alluvial fan of the Prądnik Stream at Prandoty Street (9.8 to $13.4 \mathrm{ppm}$ ), whereas the highest values have been found on the grave of Soviet soldiers, situated at a slightly lower elevation. The presence of Fe, calcium 


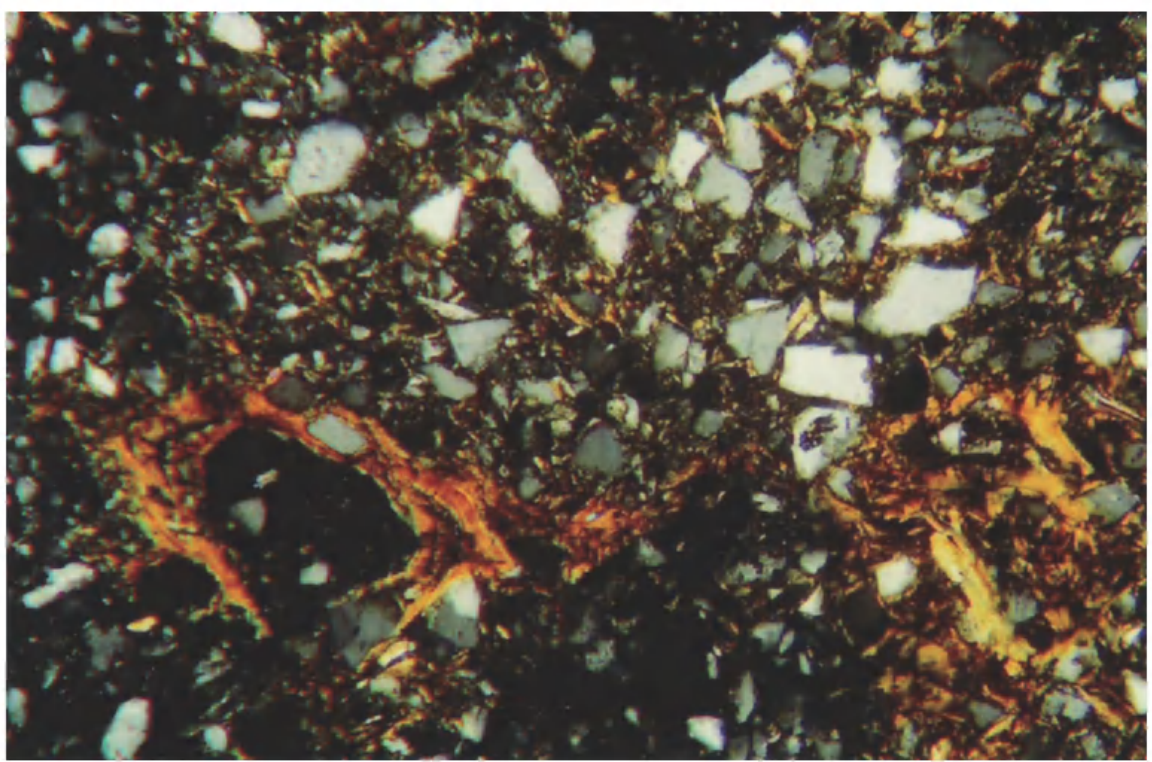

Figure 4. Ferro-organic intrusions in alluvial sediments of Grębalow cemetery soil, as observed at 80x magnification

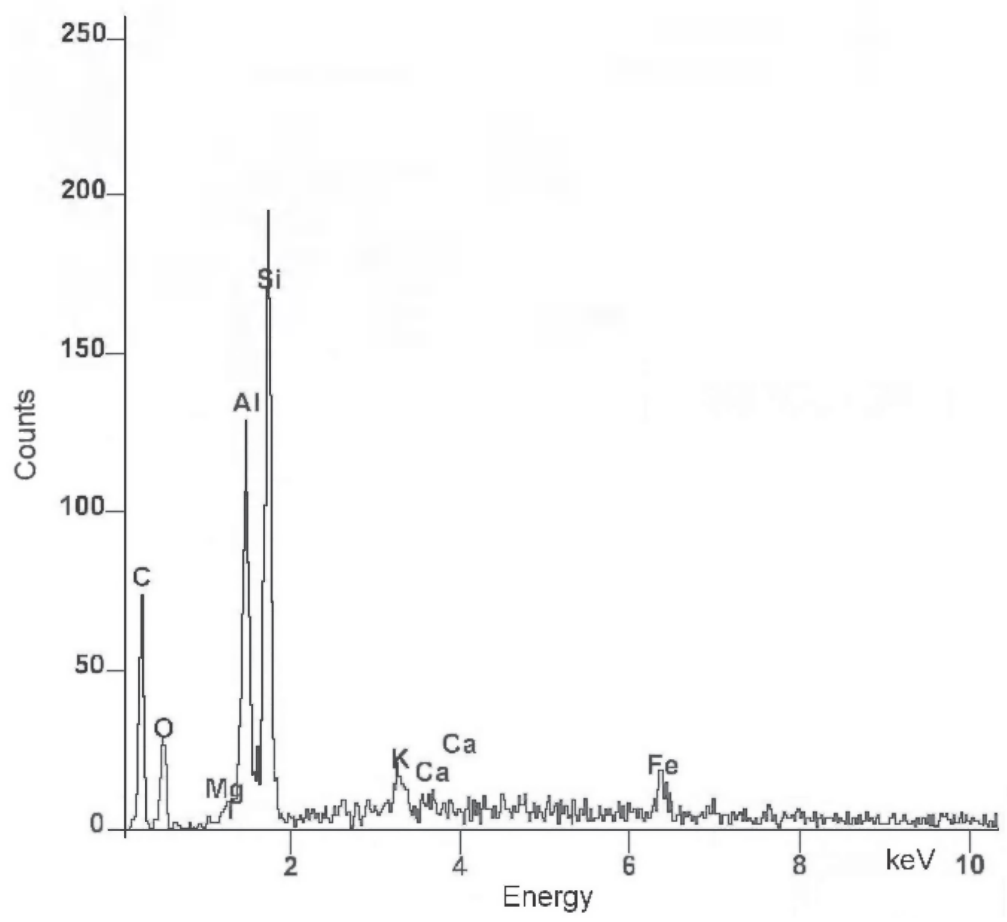

Figure 5. EDS energy spectrum of substances from the inter-grain space in a sample collected $1.6 \mathrm{~m}$ down in a grave at Grębalow 
carbonate and argillaceous materials in these sediments enhances the absorption of $\mathrm{P}$ in the aeration layer. The great thickness of this layer above the burial plots limits the influx of decomposition materials into the ground water. It was also confirmed in studies carried out in Great Britain (Trick et al. 2001).

An increased content of $\mathrm{Cr}$ in the substrate is a valuable indicator of the impact of cemeteries on the natural environment (Żychowski 2008). The samples collected from Dukla contained the highest concentrations of this element, i.e. $1.21 \mathrm{ppm}$ in the mass grave of WWI soldiers, and $2.03 \mathrm{ppm}$ in the sample from the grave of WWII Soviet soldiers. Both these cemeteries are situated close to each other and their surfaces are inclined in a south-easterly direction ( $\mathrm{Ta}$ bles 1,3 ). Some of the water penetrating the WWII grave flows down towards the other cemetery. The Cr concentrations were also relatively high in the cemeteries at Rakowicka Street and Prandoty Street (from 0.16 to $0.76 \mathrm{ppm}$ ), particularly in the mass graves of WWII soldiers (Fig. 3). Markedly lower maximum concentrations were found in Płaszów (0.41 ppm) and on the WWI graves in Podgórze $(0.14 \mathrm{ppm})$, and the graves of POWs of the WWI camp in Dębniki (the district of Cracow) in the relevant section of the Rakowice cemetery (0.14 ppm). Similar concentrations were found in the Stary Cmentarz (old cemetery) in Tarnów $(0.17 \mathrm{ppm})$ and in the WWI grave in Nowy Sącz (0.11 ppm).

In samples of sediments collected from a $1.6 \mathrm{~m}$ deep excavation of a ca. 30-year old grave in Grębalów, many fragments of organic substances were found when viewed under a polarizing microscope (Table 1). The fragments were surrounded by amorphous Fe compounds which absorb the decomposition products and lead to the emergence of organic-mineral complexes at various stages of formation (Fig. 4). Producing many complexes of this type thus limits the migration of pollutants out of a cemetery. In the spaces between quartz grains seen under the polarizing microscope at $80 \mathrm{x}$ magnification, there was a dark substance containing ca.
$1 \%$ of Fe compounds. This substance is also scattered throughout the field of view. This markedly higher Fe concentration is typical of alluvial sediments. Additionally, in the substrate of fine-grained loams at a $1.6 \mathrm{~m}$ depth in Grębalow, approx. 15\% calcium carbonate was found. This also enhances the preservation of bone structures and produces many compounds in the decomposition processes. In the EDS spectra of the samples from Grębalow, Si predominated (Fig. 5 ). The samples analysed contained great quantities of quartz - even up to $80 \%$. The fine-grained and sharp-edged quartz fragments are also locally cemented by small quantities of argillaceous minerals. These minerals also absorb decomposition products. However, no another heavy elements were found in the samples. Only aluminium which is an alkali metal and a natural component of minerals was found (Fig. 5).

It is very likely that the concentrations of decomposition products will be much higher below the graves. In the cemeteries under study, hundreds of thousands people have been buried (Tables 1,2,3). Only a few studies carried out in the world cover to the mineralogical-petrographical products of decomposition (Spongberg and Becks 2000; Trick et al. 2001; Zychowski et al. 2006b; Zychowski 2008), and as such this topic still requires more detailed studies.

The analysis of the materials collected above the burial plots indicates that the cemeteries in Krakow only slight effect the substrate in the upper parts of the profiles. The people looking after the graves come into contact with the ground of these sites. The reasons for such a low impact were sought by studying other components of the environment.

\section{CONTENT OF SELECTED ELEMENTS IN CLOVER AND MUSHROOMS}

The low impact of the cemeteries on the environment is also signified by the content of $\mathrm{P}$ in the leaves of clover collected on the studied graves and by the reference levels de- 


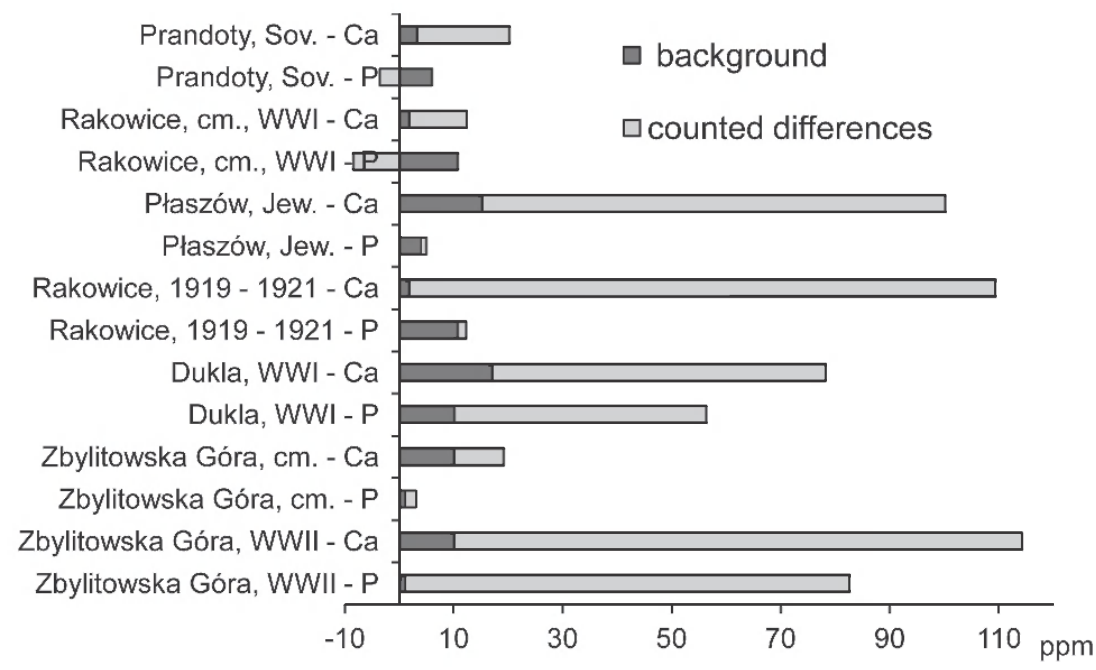

Figure 6. Differences in $\mathrm{Ca}$ and $\mathrm{P}$ contents in leaves of clover collected from selected cemeteries and other control areas. Explanations as in the tables

termined for them (Fig. 6). Clover has most of its roots mass running to a depth of 1.5 $\mathrm{m}$ and therefore the roots reach the coffins placed in graves. The differences between $\mathrm{P}$ concentrations in clover leaves calculated for graves in Kraków and those in the geochemical background are small. In several cases, the background concentrations were even higher, e.g. in the WWI mass grave in Rakowice, and in the WWII mass grave for Soviet soldiers in the cemetery at Prandoty Street (Fig. 6).

The limestone rubble and (to a lesser extent) the presence of the mass grave of POWs at the Dębniki section of the Rakowice cemetery, are probable causes of a fairly high $\mathrm{Ca}$ concentration in the clover collected from the grave and the reference concentration (Fig. 6). The difference calculated there is higher than in Płaszów. The amount of phosphorus is relatively small at the depth at which coffins are interred and above that level, as it migrates deeper into the substrate. On the other hand, Ca occurs in durable compounds and probably also in the form of rubble. On mass graves, both in Zbylitowska Góra and Dukla, the decomposition products studied occur in fairly high concentrations in the root-zone of clo- ver (Fig. 6). Numerous victims of warfare were laid in these graves at markedly lower depths, therefore the roots of the clover have access to these elements.

The little impact exerted by Kraków's cemeteries on the ground above the burial plots is further confirmed by low concentrations of $\mathrm{P}(1.3 \mathrm{ppm})$ in a mushroom found in the cemetery at Rakowicka Street (Fig. 7). The barren form of mycelium forms a solid net-type structure in light soils reaching up to $0.3 \mathrm{~m}$; whereas on heavy clay it reaches a shallow depth of $0.05 \mathrm{~m}$. The concentration of $\mathrm{P}$ in fungi on other graves is markedly higher and amounts respectively to: on mass graves in Bór near Rzeszów - 109.3 ppm, in Barwinek - 112.3 ppm, and near crematoriums in Auschwitz camp near Oświęcim 132.3 ppm (Fig. 7). It should be remembered, however, that these are sites where the greatest impact of burials on the environment was shown from among 245 cemeteries studied in south-eastern Poland (Żychowski 2008).

A relatively low $\mathrm{Fe}$ concentration was found in a mushroom growing on a grave at the Rakowicka Street cemetery $(8.9 \mathrm{ppm})$. This level is comparable with the Fe concentration in mushrooms collected from the aforementioned mass graves at the 


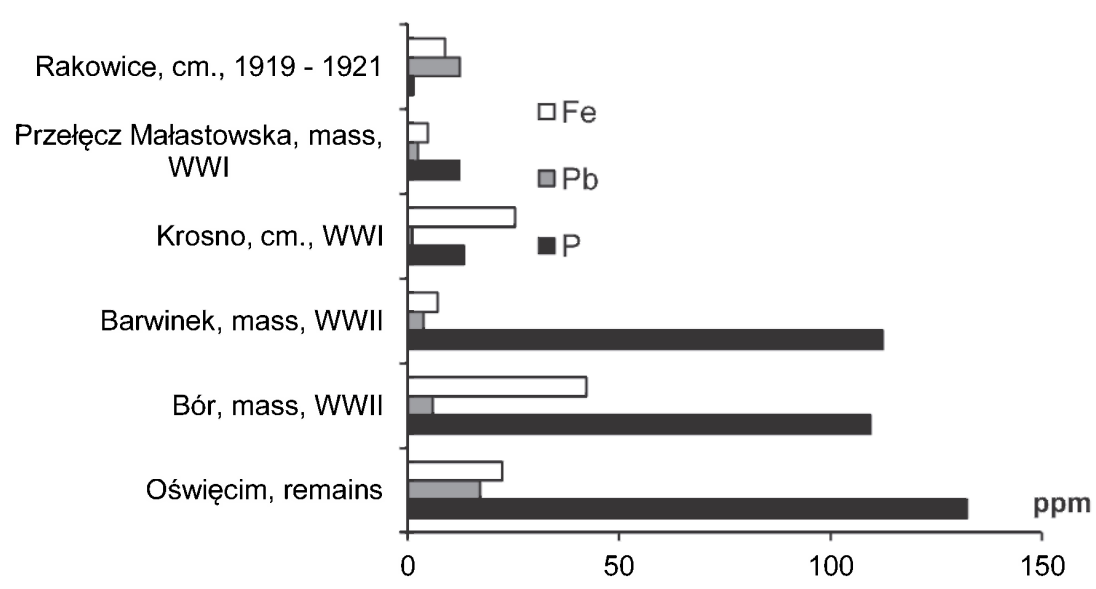

Figure 7. P, Pb and Fe contents in fungi collected at the different cemeteries.

Explanations as in the tables

Małastowska pass $(4.7 \mathrm{ppm})$ and in Barwinek - 7.14 ppm (Fig. 7). In these cemeteries, no features of land relief favourable to local ground water-logging were found (Table 2). Much higher Fe concentrations occur, however, on the river terraces in Krosno (25.41 ppm) and Oświęcim (22.48 ppm), and on a plateau in Bór $(42.25 \mathrm{ppm})$. These concentrations are favoured by the presence of sands and great fluctuations in the water table in Bór, and a loess-like substrate in Grębalów (Figs. 4, 7).

In mushrooms, the concentration of heavy elements was also relatively higher, including $\mathrm{Pb}$ (Fig. 7): at more than $12 \mathrm{ppm}$ in the mushroom collected from the cemetery at Rakowicka Street (grave dated 1919-1921). The Pb content in the substrate there was also very high. This grave in the Rakowice cemetery ranked in the second ten in the list of sites compiled with respect to $\mathrm{Pb}$ content in substrates in 245 cemeteries (Żychowski 2008), whereas mass graves at the Prandoty Street cemetery were ranked in the twenties and thirties on the list. The relatively high $\mathrm{Pb}$ concentration in the substrate and mushrooms in these cemeteries is probably also associated with pollutant emissions in this major urban area. This may particularly regard graves situated near roads with heavy traffic, e.g. in the cemetery at Rakowicka Street. The high $\mathrm{Pb}$ concentrations due to decomposition may only be the case for the huge WWII mass graves e.g. in Bór (5.82 ppm) and Oświęcim (17.5 ppm).

\section{THE WATER POLLUTION UNDERGROUND}

The ground water table under the cemeteries at Rakowicka Street and Prandoty Street remains at the depth of ca. $7.5 \mathrm{~m}$ and rises only after torrential and heavy rains. In only two cases from the 11 ions studied, did the concentrations exceed the legal permissible level required in Polish law with respect to drinking water (Dziennik Ustaw [The Official Journal of Laws] No. 32, item 284); these being phosphate and iron ions (Fig. 8). The presence of iron ions is typical of alluvial formations whereas the two-fold excess of phosphate ions is associated with the impact of cemeteries. The limits for these elements were exceeded in both cemeteries.

The concentrations of phosphate ions at the sites examined in Krakow are however, much lower than those in the ground waters under other cemeteries, e.g. on the slopes in Rymanów and Zakliczyn (Fig. 9). Similar concentrations of these ions are found e.g. in Wojnicz, where the ground water table occurs in the sediments of the Dunajec river terrace at depth of ca. $4 \mathrm{~m}$ (Table 4 ). Its fluctuations are small and occur sporadi- 


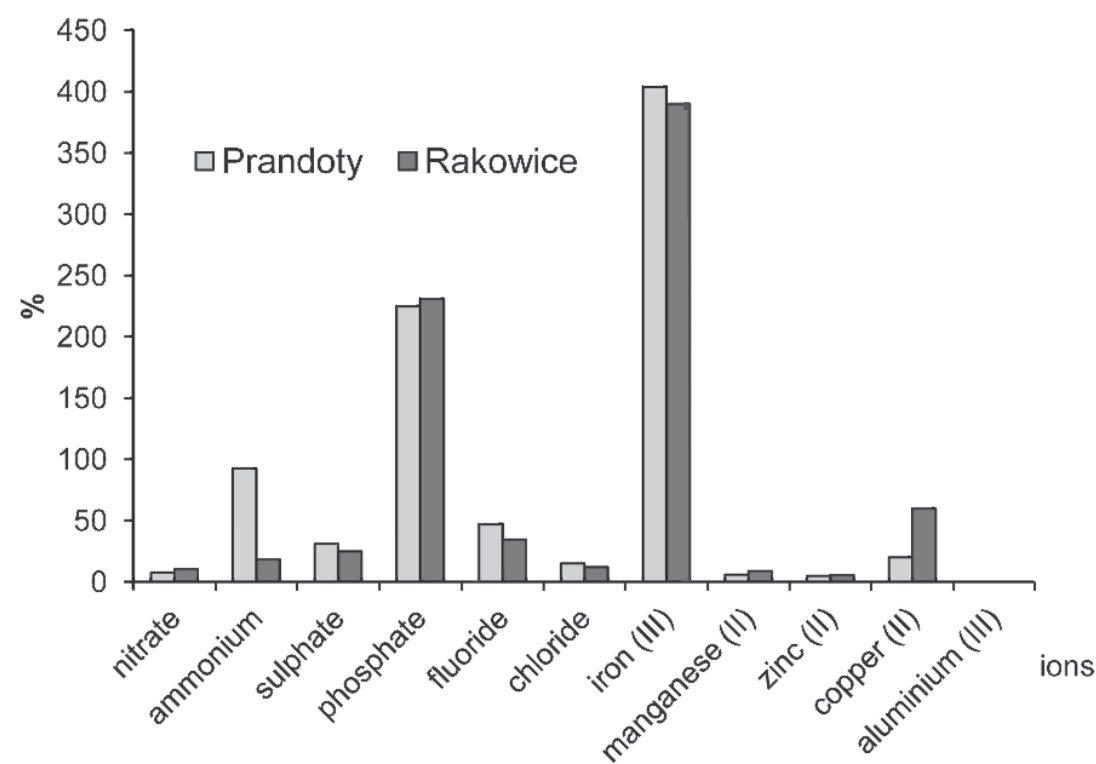

Figure 8. Percentage exceedance of permissible concentrations of ions in the ground water below cemeteries : military cemetery in Prandoty Street and Kraków Rakowicki Cemetery $\left(\mathrm{NO}_{3}{ }^{-}-\right.$nitrate; $\mathrm{HN}_{4}{ }^{+}-$ammonium; $\mathrm{SO}_{4}{ }^{2-}$ - sulphate; $\mathrm{PO}_{4}{ }^{3-}$ - phosphate; $\mathrm{F}^{-}$- fluoride; $\mathrm{Cl}^{-}$- chloride; $\mathrm{Fe}^{3+}$-iron; $\mathrm{Mn}^{2+}$ - manganese; $\mathrm{Zn}^{2+}-$ zinc; $\mathrm{Cu}^{2+}$ - copper; $\mathrm{Al}^{3+}-$ aluminium)

cally, as the distance between the cemetery and the river bed is considerable. In the ground waters under the cemeteries in Rymanów and Zakliczyn, much lower concentrations of iron ions were found (Fig. 10). In the flysh sandstone rock mantle in Rymanów and Zakliczyn where fluctuations in ground water levels are slight there is actually much less iron than in the colluvia in Biecz and the alluvia in Oświęcim where such fluctuations are more frequent. Moreover, in other studies in Poland and abroad, considerable concentrations of nitrate and ammonium ions, especially near new graves, were found (Vass et al. 1992; Żychowski et al. 2000a, b; Trick et al. 2001). These concentrations decrease with the increasing distance from the graves and decline rapidly over time (Dent 2000a, b). In Kraków's cemeteries the concentrations of these ions were fairly low. Above all, it is associated with a ground water table that is deep lying with small fluctuations. These pollutants are characteristic for the places where the water table is shallow e.g. in Biecz and Oświęcim (Table 4, Fig. 10). The ground water examined at Rakowicka and Prandoty Street is unfit for drinking purposes primarily because of the phosphate ion content. These levels of pollution are not very high, with the limiting factor there being smaller quantities of precipitation water which reaches the ground water. The reason is that rain water flows down tombstones, the concrete perimeters of tombs, and the asphalt alleys directly to the storm sewers. Gutters also help to drain out water from the roofs of cemetery buildings. The coverage by impermeable boards of the cemetery at Rakowicka Street reaches as much as $70 \%$ of its area. This factor is considered essential in limiting the ground water pollution under cemeteries. It is again indicated by the increase in pollution after downpours during which the drainage systems fail (Żychowski, Pawlikowski and Lach 2006; Zychowski 2008). The rainwater from the surface of alleys flows down on to the terrain below, which is overgrown with grass and then infiltrates the alluvial sediments. The pollution is further enhanced by the porous nature of some 


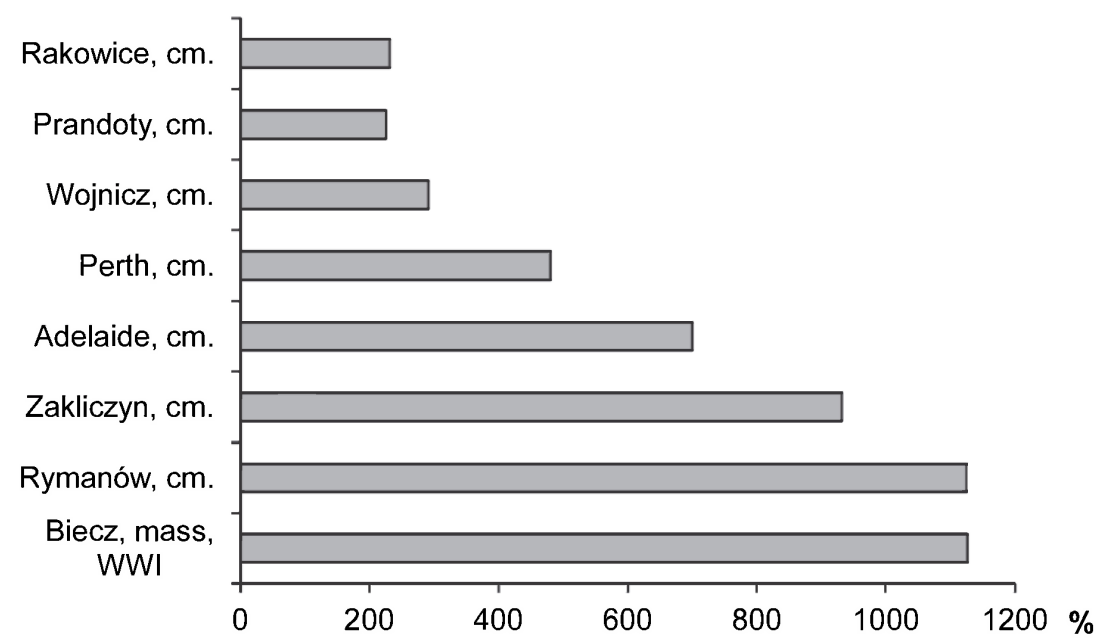

Figure 9. Cases of permissible contents of phosphate ions being exceeded in ground water beneath selected cemeteries. Explanations as in the tables

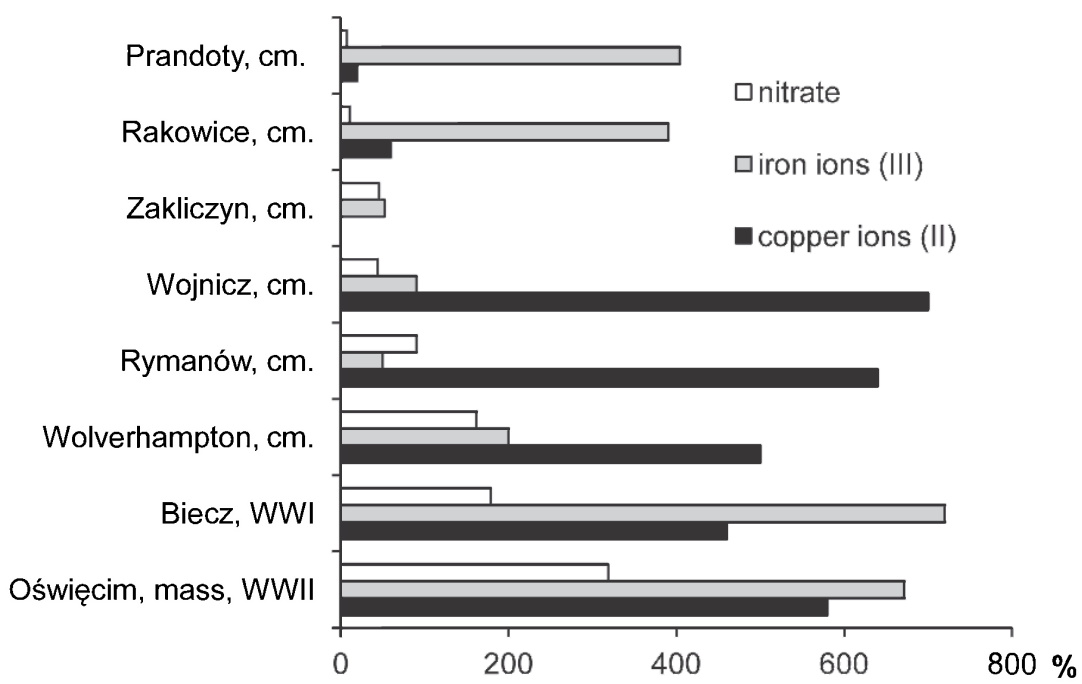

Figure 10. Comparison of exceedances of permissible contents of selected ions in ground water beneath selected cemeteries. Explanations as in tables

tombs, as the buried bodies are flooded by water which then transports the decomposition products deeper into the soil. These places are also fields of alimentation for waters.

In this study, higher elevated levels of cations, e.g. cooper ions (Fig. 10) were found more often. Other observations carried out in Kraków suggest high variability in water quality depending on the weather conditions (Żychowski 2008).

As a result of decomposition of proteins, aminoacids also enter the water (Żychowski et al. 2001, 2002, 2005). In the ground waters in Krakow, lysine was not found, but it was present in many other sites (Fig. 11). 


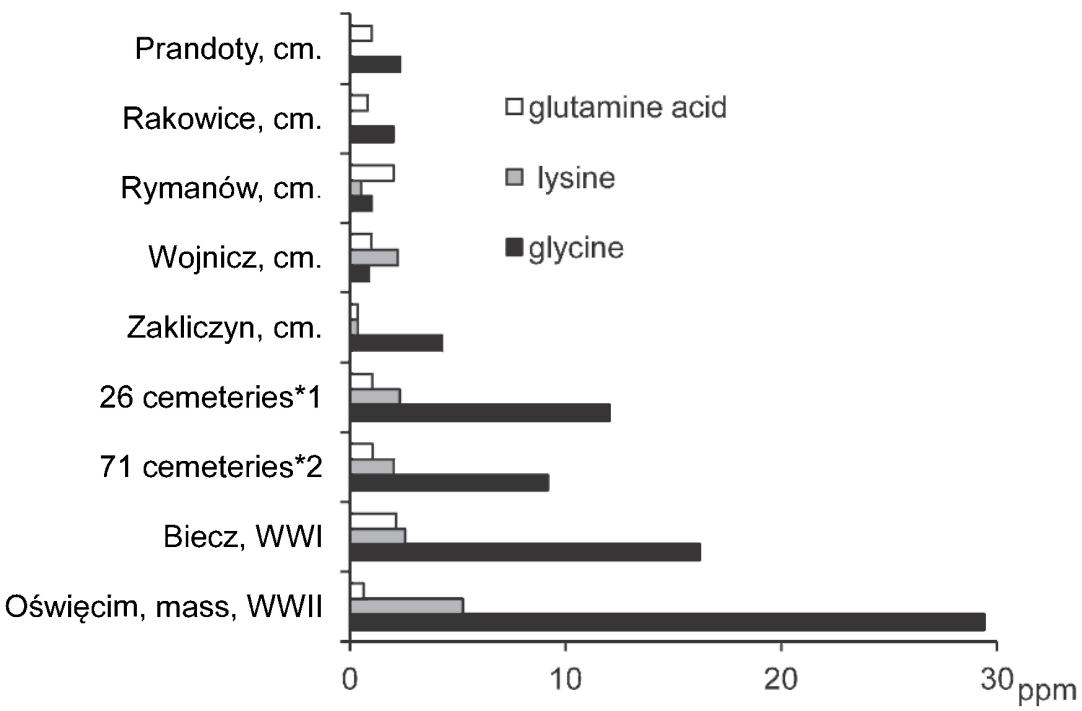

Figure 11. Average lysine, glycine and glutamine acid contents in the ground water beneath selected cemeteries. Explanations as in the tables

mean for 26 cemeteries located on terraces and for 71 cemeteries in various places.

Certain low concentration of glycine were found in the cemeteries at Rakowicka Street and Prandoty Street (Fig. 11). The limit value which unambiguously indicates the significant effect of cemeteries on the environment is $12 \mathrm{ppm}$ of glycine (Żychowski et al. 2005). Such high concentrations are favoured particularly by the environments with river terraces. The highest glycine content was noted in shallow laying ground waters in Oświęcim-Brzezinka (Table 4, Fig. 11). The migration of decomposition products in permeable substrates (eg. sands and gravels) can be limited thereby filling the space around coffins with impermeable material (Dent and Knight 1998; Zychowski et al. 2006).

In the aquatic environment, the presence of a very small quantity (ca. $1 \mathrm{ppm}$ ) of highly soluble glutamic acid was confirmed. Its concentration is comparable with the average concentration calculated for 71 other cemeteries (Fig. 11). Only in a few cemeteries was it twice as high, e.g. in Rymanów and Biecz. Among other aminoacids, trace concentrations of leucine and isoleucine were noted (in cemeteries at Rakowicka Street and Prandoty Street). At other sites, the average concentration of leucine was $3 \mathrm{ppm}$, and of isoleucine - 1 ppm (Żychowski et al. 2005).

\section{SUMMARY}

At present, the cemeteries of Kraków do not pose a major threat to the natural environment (Fig. 1). The $P$ content is markedly lower here (particularly in the Rakowice cemetery) than in other cemeteries, e.g. those situated on river terraces in Tarnów and Oświęcim (Figs. 2, 3). This minor level of impact is also signified by the concentrations of this element in the leaves of clover whose roots penetrate ground up to $1.5 \mathrm{~m}$ deep, and in a mushroom whose thallus reaches up to $0.3 \mathrm{~m}$ deep into the ground (Figs. 5, 6). The main reason for these low concentrations is the shallow level of the ground water table - e.g. in Rakowice it lays at a depth of ca. $7.5 \mathrm{~m}$ (Table 4). The thickness of the aeration zone also limits significantly the migration of decomposition products into the upper portions of the vertical profiles. The 
significant concentrations of these products in mass graves e.g. in Oświęcim and Dukla is associated with the large number of victims buried there. The presence in the substrate of Fe (Płaszów, Grębalów), Ca (Podgórze) and argillaceous minerals (Grębalów, Dukla) favours retention of the decomposition products in situ (Figs. 2, 4). The shallow occurrence of ground waters and frequent elevations of the ground water level is conducive to the migration of ions, including to the surface of the soil. In the subsurface layers they combine and form more stable compounds that have not yet to be examined at this stage of our studies. That is the reason why relatively high concentrations of the studied elements occur in the camp Płaszów, and in the Stary Cmentarz [Old Cemetery] in Tarnów - situated on the terrace of the Wątok River (Fig. 2). The presence of mass graves, particularly from World War II, increases the Cr concentration in the substrate of cemeteries, e.g. in Kraków, at Prandoty Street, and in Dukla (Fig. 3).

The quality of ground water in Rakowicka Street and Prandoty Street is unsatisfactory because of the presence of phosphate and iron ions (Figs. 8,9). Even a very thick aeration zone does not exclude the impact of cemeteries, although it does curb it's impact considerably. It should be noted that in this zone, the decomposition products accumulate, and under favourable conditions some of them can become active. Lysine was not found in the cemeteries of Kraków at all, leucine and isoleucine were only found in trace quantities, whilst glycine and glutamic acid were found in very low concentrations (Fig. 11). In the ground waters of these cemeteries, the concentrations of nitrate, ammonium, and copper (II) ions were also not as high as those found in other cemeteries e.g. in Biecz and Oświęcim (Fig. 10). The migration of decomposition products to the nătural environment is also limited by màintenance work around the cemeteries; namely: sealed vaults, the concrete surrounds of graves, and a system of gutters and storm water sewers along the alleys. The variation in ion concentrations in water under the cemeteries depends, however, on weather conditions (Żychowski 2008). The elevation of the ground water table in the alluvial fan of the Prądnik stream could be dangerous. The likelihood of this occurring is presently very low but nevertheless this risk is there, and is associated with the increased amount of precipitation in recent years and with the forecast of further increases till the year 2020 , along with the increasingly frequent occurrence of violent downpours.

New locations of cemeteries call for legislative restrictions and regulations governing the maintenance of environment-friendly conditions in the burial sites. The legal provisions applying to-date do not guarantee siting decisions compliant with the principle of eco-development.

A partial solution to the problem highlighted in this study would be to build a crematorium. In many countries around the world a major proportion of the deceased are cremated e.g. in the Czech Republic and the Scandinavian countries - nearly $70 \%$, and in Japan $-98 \%$.

\section{DISCUSSION}

In this study, the decomposition products accumulated within the limits of cemeteries were treated as a 'black box', as have been done by most of the researchers around the world (Dent 2000b). There are still many issues which were not considered in this study. Finding solutions to these would require different research methodology, greater intervention in the environment of cemeteries, and definitely the provision of greater funding. Also needed would be the permission of the administrator for each cemetery to carry out examinations on these sites. Apart from all these aspects it is a major endeavour, both in terms of the quantity of sites and the interdisciplinary approach required.

The research projects conducted by particular scientists in various places worldwide involve a relatively low number of cemeteries. For example, in his Ph.D. thesis, Matos (2001) studied two cemeteries, whereas 
Dent investigated nine (Dent 2004). Therefore they focused on the problems which in these sites are essential to the recognition of the contamination problem.

The majority of researchers recognize the importance of hydrogeology (e.g. Dent 2004). In many cases they had difficulties in getting familiar with the routes of water circulation. There are some who ascribe a significant role to climate (e.g. Rodrigues, Pacheco 2003), whilst the American scientists list additional potential contaminants, such as varnishes, sealing agents, conservants, pesticides and the like (e.g. Spongberg, Becks 2000).

In future, the environmental impact of cemeteries should be monitored more effectively. This will allow one to estimate how, for example, contamination is affected by factors such as the weather. This study does not consider the impact/extent of extreme conditions, such as those associated with major fluctuations in ground water tables.

In future, more attention should be given to the aeration zones where coffins are deposited. Another interesting aspect to study would be to find the effect of subsequent burials in the same place. Given the present shortage of land for burials and the need to allocate land for new cemeteries, the studies reported in this paper are of vital importance.

\section{CONCLUSIONS}

The impact of Krakow's cemeteries on the natural environment is very low, owing to the fact that:

- ground water under the cemeteries is deep lying;

- fluctuations in ground water tables are small and rare;

- significant proportions of the areas of cemeteries are covered by impermeable surfaces, e.g. rock boards, concrete surrounds of tombs, asphalted paths etc. which results in a small area of ground water alimentation;

- cemeteries are well drained e.g by gutters around larger tombs, drainage of precipitation water to storm sewers etc.;
- the substrate contains sorbents of decomposition products e.g. calcium carbonate, Fe compounds and argillaceous minerals;

- tombs are generally well maintained and hence water cannot penetrate into them and flush out decomposition products.

\section{ACKNOWLEDGEMENTS}

My sincere thanks are due to Mr. Mariusz Kolber for the spectrommetric and chromatographic analyses, and to Professor M. Pawlikowski as well as to the microscopic laboratory of the Technical University of Mining and Metallurgy (AGH) in Kraków.

\section{REFERENCES}

Arrhenius, O. (1929), Die Phosphatfrage, Zeitschrift fur Pflanzenernahrung, Dundung und Bodenkunde, 14A: 185-194.

Dent, B. B., Knight, M. J. (1998), Cemeteries: a special kind of landfill. The context of their sustainable management. Groundwater: Sustainable solutions, Conference of the International Association of Hydrogeologists, Melbourne, 8-13 Feb. 1998: 451-456.

Dent, B. B. (2000a), Cemetery decay product profiles: Two cases in Australian, unconsolidated, sandy aquifers. Searching for a sustainable future, 15th Australian Geological Convention, Sydney, 3-7 July, Geological Society of Australia, Abstracts, 59: 130.

Dent, B. B. (2000b), Decay products in cemetery groundwaters, in: Geology and Sustainable Development: Challenges for the Third Millennium, 31st International Geological Congress, Rio de Janeiro, 6-17 August, CD-ROM.

Dent, B. B. (2004), The hydrogeological context of cemetery operations and planning in Australia, Ph.D thesis, University of Technology, Sydney, Australia, 1-453, <http:// utsescholarship.lib.uts.edu.au/dspace/ bitstre $\mathrm{m} / \mathrm{h}$ andle $/ 2100 / 963 / 02 \mathrm{~W}$ hole pdf? sequence $=6>$, Last accessed 19 Nov. 2011 .

Fisher, G. T., Croukamp, L. (1993), Groundwater contamination and its consequences resulting 
from the indiscriminate placing of cemeteries in the third world context, Conference: Africa Needs Groundwater, University of the Witwatersrand, Johannesburg, South Africa.

Forbes, S. L. (2002), An investigation of the formation of adipocere in grave soils, $16^{\text {th }}$ International Symposium on the Forensic Sciences, Canberra, 12-17 May, Forensic Sciences Outcomes for Society Handbook, 162-163.

Joner, E. J., Briones, R., Leyval, C. (2000), Metal-binding capacity of arbuscular mycorrhizal Mycelium, Plant and Soil, 226: 227-234.

Khan, A. G., Kuek, C., Chaudhry, T. M., Khoo, C. S., Hayes, W. J. (2000), Role of plants, mycorrhizae and phytochelators in heavy metal contaminated land remediation, Chemosphere, 41: 197-207.

Knight, M. J., Dent, B. B. (1995), A watery grave the role of hydrogeology in cemetery practice, ACCA News, Summer, 19-22.

Knight M. J., Dent, B. B. (1998), Sustainability of waste and groundwater management systems, in Weaver, T.R., Lawrence, C. R. (eds.), Proceedings of the International Association of Hydrogeologists International Groundwater Conference. Groundwater: Sustainable Solutions. Melbourne Australia 8-13 February 1998, Brisbane, 359-374.

Krupa, P., Kozdrój, J. (2004), Accumulation of heavy metals by ectomycorrhizal fungi colonizing birch trees growing in an idustrial desert soil, World Journal of Microbiology and Biotechnology, 20 (4): 427-430.

Lovera, M., Cuenca, G. (1996), Arbuscular mycorrhizal infection in Cyperaceae and Gramineae from natural, disturbed and restored savannas in La Gran Sabana, Venezuela, Mycorrhiza, 6: 111-118.

Marcinek, J., Wiślański, T. (1959), Sprawozdanie z wstępnych badań gleboznawczych na obiektach archeologicznych w Strzelcach i Glogówku w pow. Mogilno w 1956 r. [Report on preliminary soil tesearch in the archeological sites in Strzelce and Glogówek localities of the district of Mogilno in 1956], Sprawozdania Archeologiczne, 7: 77-93.

Matos, B. A. (2001), Avaliaçao da ocorrência e do transporte de microrganismos no aqüífero freático do cemitério de Vila Nova Cachoeirinha, município de Sao Paulo, Tese (Doutora- do) - Instituto de Geociencias, Universidade de Sao Paulo, <http://www.teses.usp.br/teses/ disponiveis/44/44133/tde-19122001-082301/ publico/TDE.pdf $>$.

Miller, R. M., Jastrow, J. D. (2000), Mycorrhizal fungi influence soil structure, in Kapulnik, Y., Douds, D.D. (eds.), Arbuscular Mycorrhizas: Physiology and Function, Kluwer Academic Publishers, Netherlands, 3-18.

Pacheco, A., Mendes, J. M. B., Martins, T., Hassuda, S., Kimmelmann, A. A. (1991), Cemeteries: A potential risk to groundwater, Water Science and Technology, 24 (11): 97-104.

Rodrigues, L., Pacheco, A. (2003), Groundwater contamination from cemeteries cases of study, in: International Symposium Environment 2010 Situation and Perspectives for the European Union, Porto 6-10 May 2003, Portugal.

Smith, S. E., Read, D. J. (1997), Mycorrhizal symbiosis, Academic Press, London.

Spongberg, A. L., Becks, P. M. (2000), Inorganic soil contamination from cemetery Leachate, Water, air, and soil pollution, 117: 313-327.

Tam, P. C. F. (1995), Heavy metal tolerance by ectomycorrhizal fungi and metal amelioration by Pisolithus tinctorius, Mycorrhiza, 5: 181-187.

Trick, J. K, Klinck, B. A., Coombs, P., Chambers, J., Noy, D. J., West, J., Williams, G. M. (2001), Pollution potential of cemeteries: Impact of Danescourt Cemetery. Wolverhampton, British Geological Survey Internal Report, IR/01/104, 29.

Ucisik, A. S., Rushbrook, P. (1998), The impact of cemeteries on the environment and public health - an introduction briefing, Regional Office for Europe, World Health Organization, Rept. EUR/ICP/EHNA 010401 (A), 1-11.

Van Haaren, F. W. J. (1951), Cemeteries as sources of groundwater contamination, American Institute of Chemical Engineering, Water, 35 (16): 167-172.

Vass, A. A, Bass, W. M., Wolt, J. D., Foss, J. E., Ammons, J. T. (1992), Time since death determinations of human cadavers using soil solution, Journal of Forensic Sciences, 37 (5): 1236-1253.

Zychowski, J. (2007), Wplyw masowego grobu na zawartość wybranych zwaqzków organicznych $w$ wodzie gruntowej [The effect of mass grave 
on the content of selected organic compounds in groundwater], in Ziulkiewicz, M. (ed.), Stan $i$ antropogeniczne zmiany jakości wód w Polsce [State and anthropogenic changes of water quality in Poland], Vol.5, Wydawnictwo Uniwersytetu Łódzkiego, Łódź, 359-366.

Żychowski, J. (2008), Wplyw masowych grobów z I i II wojny światowej na środowisko przyrodnicze [The effect of mass graves from WW1 and 2 on the natural environment], Wydawnictwo Naukowe Akademii Pedagogicznej, Kraków.

Żychowski, J. (2010), Wplyw krakowskich cmentarzy na środowisko przyrodnicze [The influence of cemeteries of Krakow on the environment], Przeglad Geograficzny, 82,3: 409-434

Żychowski, J., Lach, J., Kolber, M. (2000a), Whaściwościfizyczno-chemiczne wód podziemnych nekropolii Polski południowo-wschodniej [Physico-chemical features of ground waters on cemeteries of south-eastern Poland], in Burchard, J. (ed.), Stan i antropogeniczne zmiany jakości wód w Polsce [State and anthropogenic changes of water quality in Poland], Vol. 1. Wydawnictwo Uniwersytetu Lódzkiego, Łódź, 249-261.

Żychowski, J., Lach, J., Kolber, M. (2000b), Przestrzenna zmiennośc chemizmu wód podziemnych $w$ otoczeniu nekropolit $w$ Polsce poludniowej [Physico-chemical features of ground waterss on cemeteriess of south-eastern Poland], in Burchard, J. (ed.), Stan $i$ antropogeniczne zmiany jakości wód w Polsce [State and anthropogenic changes of water quality in Poland], Vol. 1, Wydawnictwo Uniwersytetu Łódzkiego, Lódź, 261-269.

Zychowski, J., Lach, J., Kolber, M. (2002), Zróżnicowanie zawartości lizyny $i$ kwasu glutaminowego $w$ wodach podziemnych na wybranych cmentarzach w Polsce poludniowo-wschodniej [The differentiation of lysine and glutamic acid contents in the ground water in cemeteries of south-eastern Poland], in Burchard, J. (ed.), Stan $i$ antropogeniczne zmiany jakosci wód $w$ Polsce [State and anthropogenic changes of water quality in Poland], Vol. 2, Wydawnictwo Uniwersytetu Łódzkiego, Lódź, 241-251.

Żychowski, J., Lach, J., Kolber, M. (2003), Występowanie aminokwasów: glicyny, leucyny i izoleucyny w wodach podziemnych na cmentarzach zlokalizowanych w różnych środowiskach [The occurrence of amino acids of glycine, leucine and isoleucine contents in the ground water in cemeteries located on different bedrock], Przeglad Geologiczny, 51 (11): 962-963.

Żychowski, J., Lach, J., Kolber, M. (2005), Zróżnicowanie zawartości glicyny, leucyny $i$ izoleucyny w wodach podziemnych na cmentarzach zlokalizowanych w różnch podtożach [The differentation of glycine, leucine and isoleucine contents in the ground water in cemeteries located on different bedrock], in Burchard, J. (ed.), Stan $i$ antropogeniczne zmianyjakości wód w Polsce [State and anthropogenic changes of water quality in Poland], Vol. 3. Wydawnictwo Uniwersytetu Lódzkiego, Łódź, 281-290.

Żychowski, J., Lach, J., Kolber, M. (2006a), Wplyw podloża z masowym pochówkiem z II wojny swiatowej na sklad chemiczny wód gnuntowych [The effect of bedding of mass graves from WW2 on chemical composition of ground waters], in Ziułkiewicz, M. (ed.), Stan i antropogeniczne zmiany jakości wód w Polsce [Státe and anthropogenic changes of water quality in Poland], Vol. 5, Wydawnictwo Uniwersytetu Łódzkiegoo, Lódź, 349-357.

Żychowski, J., Pawlikowski, M., Lach, J. (2006b), Produkty dekompozycji szczątków organicznych na przykladzie masowego grobu w Niepolomicach [Products from decomposition of organic compounds, example of a mass grave in Niepolomice neár Crácow], Kwartâlnik AGH, Kraków, Geologia, 32 (2): 203-224.

Paper first received: September 2011

In final form: December 2011 
http://rcin.org.pl 